\title{
Ethics and Integrity in Social Media
}

Nor Zaina Zaharah Mohamad Ariff, Norliya Ahmad Kassim, Mohd. Shamsul Mohd. Shoid, Kasmarini Baharuddin

To Link this Article: http://dx.doi.org/10.6007/IJARBSS/v11-i5/9775 DOI:10.6007/IJARBSS/v11-i5/9775

Received: 23 March 2021, Revised: 27 April 2021, Accepted: 10 May 2021

Published Online: 19 May 2021

In-Text Citation: (Ariff et al., 2021)

To Cite this Article: Ariff, N. Z. Z. M., Kassim, N. A., Shoid, M. S. M., \& Baharuddin, K. (2021). Ethics and Integrity in Social Media. International Journal of Academic Research in Business and Social Sciences, 11(5), 310318.

Copyright: (c) 2021 The Author(s)

Published by Human Resource Management Academic Research Society (www.hrmars.com)

This article is published under the Creative Commons Attribution (CC BY 4.0) license. Anyone may reproduce, distribute, translate and create derivative works of this article (for both commercial and non-commercial purposes), subject to full attribution to the original publication and authors. The full terms of this license may be seen at: http://creativecommons.org/licences/by/4.0/legalcode

Vol. 11, No. 5, 2021, Pg. 310 - 318

Full Terms \& Conditions of access and use can be found at http://hrmars.com/index.php/pages/detail/publication-ethics 


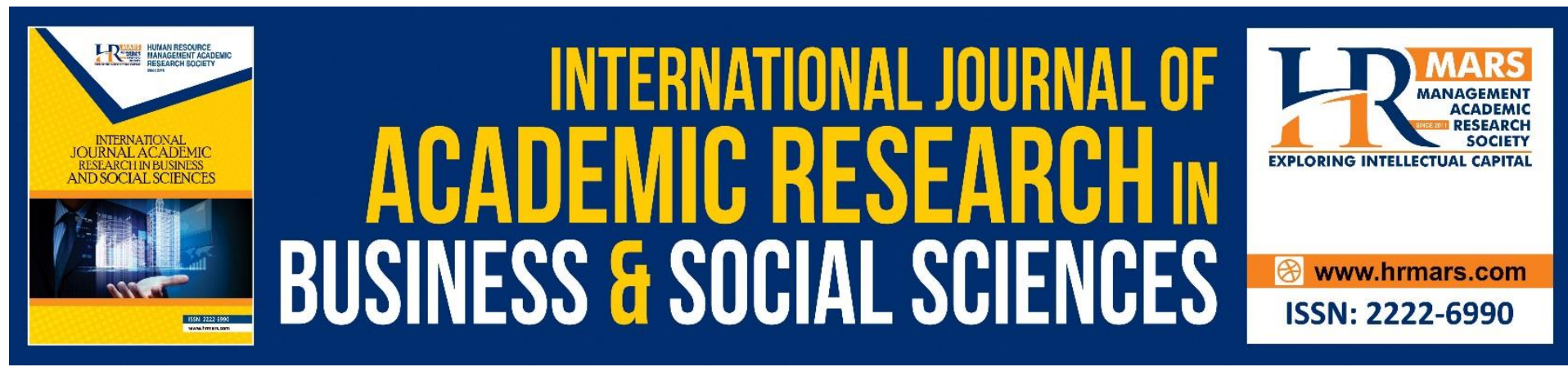

\title{
Ethics and Integrity in Social Media
}

\author{
Nor Zaina Zaharah Mohamad Ariff, Norliya Ahmad Kassim, \\ Mohd. Shamsul Mohd. Shoid, Kasmarini Baharuddin \\ Faculty of Information Management, Universiti Teknologi MARA (UiTM), Malaysia \\ Email:norzaina@uitm.edu.my,norliya@uitm.edu.my,shamsulshoid@uitm.edu.my, \\ kas@uitm.edu.my
}

\begin{abstract}
The proliferation of social media has become extremely famous among the societies. Societies accept this technology as an important amenity in their daily lives. However, of each of the advancement of the technology, it must be good for mutual benefits although there are the cons on the misuse of this technology. Here, the issue of ethics and integrity in the use of social media are emphasized to show people that the misuse of the technology can happen unnoticed or unplanned. Currently, hot topics or issues on social ethics and integrity in the media have so often given a big impact in people's lives. The purpose of this paper is to discuss the matters of ethics and integrity in social media. It mentions the societies as the startingpoint for addressing major challenges and issues, reviews literature on social media trends and research, draws on examples of influences and also personal competencies required for ethics and integrity. The review from various empirical studies and literature reviews will focus on two (2) major aspects; leadership and education which will be a great contribution to any research done in this area in the near future.
\end{abstract}

Keyword: Ethics, Integrity, Social Media, Leadership and Education.

\section{Introduction}

The popularity of social media brings to the transaction of information quickly and easily. The widespread use of social media today does not count the strata of society of all ages, whether for children, youth or adults. The onset of various episodes of the life and arrangement of the human life cycle, which relies heavily on media technology to enhance the everyday affairs of human life. The medium of social media introduces the use of mediated-communication into the relationship process and have organizational procedures of software that control the exchange of interpersonal information in social media networking sites such as text messaging, instant messenger programs, bulletin boards, online games, online education and much more. All of these applications are fit into a larger scenario of social media which support social collaboration. The term of social media is an umbrella concept that describes social sites and social networking.

In pursuit of modernity that use social media, people need to realize that they need to have the values of ethics and integrity in the management of handling with social media. Ethics means sound moral principles and it focuses on a good grip of clean character, while 
integrity refers to the set of superior quality that exists among individuals and the quality is based on the principles adhere that to honesty and high moral practice. Societies faced the real world of extraordinarily advanced technology with high impact challenges of personal competencies which requires them to be more alert to their ethics and integrity while conducting any occasions from the social media. If the ethics and integrity are ignored while using social media, the problem of misuse will appear.

The increasingly widespread use of social media has brought all the advantages and disadvantages of their used. Here the existence of social media's misuse arises in every aspect of human life. Further, social media sites have become popular sites for youth culture to explore them, and share every moment and activities in their daily life. Teenagers freely give their personal information to join social networking on the media social sites (Barnes, 2006). Social sites allow its users to create web pages or profiles that provide information about themselves and are available to other users; and also offers a mechanism for communication with other users, such as a forum, chat room, email or instant messenger. The unawareness of the usage of social media sites is causing cases of online friendship that turned violent or even homicidal. The misuse of technology from social media lead to the unethical attitude and also zero practices of integrity in their life.

Kaplan \& Haenlein (2010) define social media as a group of internet-based applications that build on the ideological and technological foundations of Web 2.0, and that allow the creation and exchange of user-generated content. To understand more easily, it is necessary to know the purpose of the media first. Media is one of the means of communication for example newspapers and radio. Thus, social media means the social instrument of communication. Social Media is an online media and users can easily communicate in any manner or through blogs, wikis, forums and social networks like Facebook, Twitter, Myspace and more. Social networking is a method which is often used by people in the world. Traditional media such as newspapers or television has limitations to the user because the user has difficulty to give an opinion or an independent view on something published. However, with the presence of social media, users can easily throw their opinion and be able to communicate to the world without barriers.

Continuity of social media usage among the public is through the nature of ethics and integrity. Ethics, in general, is the superior quality of the overall shape and volume of the individual and the organization. Integrity is closely related to ethics. It is based on ethics in action in everyday situations (Malaysian Institute of Integrity and National Integrity Plan, 2016).

Individual ethics is a set of values in a person that enables him to distinguish between right and wrong, good and bad, that should and can do, and what should not and cannot do. The choice between these things always happens on the job, in everyday life, or when interacting with others. For those who work in an organization, the organization's ethics produce guidelines for employees to perform tasks, such as the need to hold on to the clean, efficient, trustworthy, honest, truthful, transparent, accountable and fair. As organizations deal with people, organizational ethics also demand that comply with the Charter.

Professional ethics is a code that outlines what should and should not be made by professional practitioners. Among the professions that have a code of ethics, include medical, judicial, legal, accounting, journalism and teaching. For example, a doctor or a judge is bound by professional ethics. An editor, writer or journalist will have to stick to the ethics of journalism in the dissemination of information through the media. Similarly, a teacher must comply with ethics. 
Integrity, in general, is the superior quality that exists as a whole and on individual and organizational strife. Integrity is closely related to ethics. It is based on ethics and ethical reflection in everyday actions. Individual integrity is harmony between what the individual with what he fulfilled; consistency between actions with moral principles, ethics and law; and concordance between self-interest and the public interest. The integrity of the organization is reflected in the formulation and implementation of codes of ethics, charter or systems and work processes and adherence to best practices. The organization should have code of ethics, and being practiced by the members of the organization until it becomes a habit and eventually becomes the organization's culture.

For individuals who hold their trust as occupying public office, trust and integrity mean implementing powers entrusted by the public interest. The servant cannot abuse his power for personal, family, relatives or kin. When there is a conflict of interest, it must be resolved by giving precedence to the public interest. Thus, the servant must be transparent and sincere, must take responsibility for his boss, subordinates, and to other parties.

Civilizing ethics and integrity of the individual must go through a lifelong process. It involves the role of various public institutions such as family, education, and mass media. Civilizing ethics and integrity within the organization demand that leaders act as an example (role model) while the other members practice it in their actions. Organizations also need to have clear and realistic goals that are shared by members of the organization. It is necessary to have good systems and procedures to ensure the smooth execution of their duties in an efficient, organized, and accurate, in addition to having a system of quality control, monitoring, reward, and punishment.

\section{Literature Review Leadership}

A leader is a person who is recognized by one or more than one person, when the leaders have influence, authority and power (Ramaiah, 1999). Professional level leadership in an organization is very important in creating a conducive working atmosphere and competent. Eddy (2012), investigated the CEO leadership styles and the implementation of organizational diversity practices which affect the social values. Specifically, this study examines the CEO transformation and transactional leadership in relation to organizational diversity practices. The results suggested that transformation leadership is most strongly associated with the implementation of diversity practices. These findings extend previous work and highlight the central role that organizational leaders may play in the success of this implementation practices. Organization is a complex adaptive system operating which needs an extra demand on leaders. Hence, leadership requires a leader of extraordinary abilities.

Leadership in relation to ethics might go wrong in several ways which may lead to a tighter relationship between leaders and followers. Michael (2014), came out with assumptions of a good character of leaders. Leaders whether they are university presidents or senators, corporation executives or newspaper editors, school superintendents or governors, contribute to the continuing definition and articulation of the most cherished values of our society. Leadership must be able to differentiate not only between leadership and good ethical character, but also between leadership and power, authority, influence, managerial ability, and charisma.

According to social media expert Li (2010), in his book 'Open leadership: How social technology can transform the way you lead", by making information flow easily throughout the organization, leadership, and social media influence how decisions are made. According 
to $\mathrm{Li}$, becoming a leader of the era of social media is a huge challenge. Adaptation of this technology led leaders who should rethink of their view on leadership when they will open up and share information and make the right decisions for the good of all (Widodo, 2011).

Future leaders depend on social media where they can really master social media will be able to significantly increase their influence, and not just in their direct business. Leaders who can create a strong leadership profile with a large follower will significantly increase their ability to influence (Gordon, 2014). There are organizations in which people are not encourage to join in with the rise of social media, as it is viewed as something the organization cannot control. One thing that can be make connections of tomorrow will not be the same as those of today and leaders will need to keep up.

A study by Culnan (2010) focused on the challenges that firms face as they implement social media applications to interact with customers, on the value such applications provide It can be concluded from this study; more and more firms are using, or plan to use social media platforms such as Twitter, Facebook, blogs and client-hosted forums to communicate with their customers. They developed guidelines from this analysis of the Fortune 500's use of social media and case studies of how the large U.S corporations are successfully using popular social media platforms.

Deiser (2013) highlighted in his article about skills needed by a leader to achieve a competitive advantage. He mentioned that, many organizations have been responding to that new reality, realizing the power and the potential of this technology for corporate life: wikis enable more efficient virtual collaboration in cross-functional projects; internal blogs, discussion boards, and YouTube channels encourage global conversations and knowledge sharing; sophisticated viral media campaigns engage customers and create brand loyalty. The dynamics of social media amplified the need for qualities that have long been a staple of effective leadership, such as strategic creativity, authentic communication, and the ability to deal with a corporation's social and political dynamics and to design an agile and responsive organization. Also displayed, six dimensions of social media literate leadership; advisor, architect, and Analyst are in the strategic level while; producer, distributor, and recipient are at the personal level.

Ethical and empowering leader behaviors are associated with the effectiveness of Leaders Member Exchange (LMX) theory. Leader-Member Exchange theory of leadership focuses on the two-way relationship (dyadic relationships) between supervisors and subordinates. The theory assumes that leaders develop an exchange with each of their subordinates, and that the quality of these leader-member exchange (LMX) relationships influences subordinates' responsibility, decision influence, access to resources and performance. Deluga's (1998) theory promotes positive employment experiences and also augments organizational effectiveness. Seibert (2003) started that, leader-member exchange focuses on increasing organizational success by creating positive relations between the leader and subordinate.

Some research suggested that leaders gave responsibility to enhance motivation and work performance of subordinates through delegating authority for decisions related to the work (Huang et al., 2010; Yukl \& Becker, 2006; Chen et al., 2011; Kirkman \& Rosen, 1999). An ethical leader is someone who can be trusted, unbiased decision maker, and give personal care for the welfare of others. They may be involved in a variety of social exchange with a subordinate, which in turn is expected to be positively associated with loyalty to the leader and commitment to the work unit and organization. 


\section{Education}

Integrity in the education field can be defined as honest education work such as; the ideas and the writing of others are properly cited; students submit their own work for tests and assignments without unauthorized assistance; students do not provide unauthorized assistance to others, and students report their research or accomplishments accurately. Students are increasingly exposed to technological developments that affect many areas of their learning. The technology of social media through the medium of websites made a huge impact in supporting the teaching and learning process. Website is designed to provide students and educators with resources and consulting links to advance academic integrity in their school, a free network for communication between any educator interested in advancing integrity and links to support with integrity program that include a research-based student evaluation instrument, e-lessons to resist plagiarism, a toolkit for school-wide project work, and on-line professional development in support of creating classroom lessons for student moral functioning.

A study on ethics education and ethical climate to influence the likelihood of engaging in ethical behavior explained findings on both ethics education and ethical climate had a direct impact on a student's likelihood of engaging in the ethical behavior. Results for nonexperiential learners that relates to ethical climate were non-significant, but ad hoc analysis indicates ethical climate significantly impacted likelihood to engage in ethical behaviors (Leanna, 2014). The findings have practical implications for how universities should utilize learning spaces both inside and outside the classroom to stimulate deep learning and be more effective in sensitizing students to ethical behavior. The results support using formal and informal learning spaces to stimulate deep learning as it relates to ethics education in universities.

Khalidah et al. (2014) studied the level of ethics at Malaysian private higher learning institution by comparing the foundation and undergraduate technical-based. The study highlighted some points on; ethical value among Generation Y; ethical values among university students; and ethics curriculum in the Malaysian Educational System. The research instruments are divided into five dimensions used in the study; integrity, honesty, respect, courage and self-control. Findings from the results showed non-significant between the two cohorts in terms of their level of integrity, self-control, and respects for humans and nonhumans, the foundation's students are found to be more honest and courageous in a collective setting compared to the final year students.

Moran (2011), came out with a research project on how faculty use social media in their teaching and learning activities in higher education institutions. The faculty believes that social media sites offer value in teaching and also give valuable tools for collaborative learning. From the survey conducted, findings from the faculty awareness of social media are examined within the level of faculty members' where they are very familiar with social media and over $90 \%$ reported they are aware of such sites as MySpace, Facebook, Twitter, YouTube, and blogs. In addition, it is stated also that social media supported their professional careers as social media are making easy for them to get faster information for their teaching and learning process. Ninety one percent of faculty using social media for professional purpose and in the classroom includes a large portion that uses social media for both purposes. Seventy eight percent of all faculty reported using at least one social media site in support of their professional career activities. 
Skype with students for the sake of learning distance learning processes is one of the social media contributions to support teaching and learning activities. From these activities, students may listen, take notes, asked questions and engaged in discussion. Even though not sharing a physical space together, the experiences are remarkably similar to experience with students in the actual world (Mark, 2010). Skype lecture was just part of the rapidly expanding universe of social media in higher education.

The most significant benefit of social media for higher education is a trait that seems to turn out students who entered the university. The main educational implication of social media is a trait that seems to change the relationship with information and knowledge students. In fact, it can be said that social media supports the use of knowledge and the construction of knowledge that is very different to the principles of epistemology formal education and individual teaching. On the changes in the social media era in education, Thomas \& Seely (2011) represented the Description Brown of technology, where to improve new culture of learning - based on the principles of collective exploration, play and innovation rather of individual instruction. And chiming with current constructivist style and socio cultural theory, several lists of education has led to fully assess the nature of learning as the user changes the relationship of social media that seems to have the information.

Goodyear \& Ellis (2008) argued that many educators believed that social media can be used successfully to support the teaching and learning process. While most structured implementation of social media in the university environment imagine the level of user driven education, that is allow students to take a more active role in what they learn and how and when they knew it. However, many educators believed that university can accommodate (and benefit from) this change of emphasis (Lee \& McLoughlin, 2010).

\section{Conclusion}

In conclusion, some recommendations can be concluded in this study to address the issues of technology abuse in social media, where the public is advised to be aware that they should have ethical values and integrity in the management of social media operations. This issue turned out to be widespread unnoticed or unplanned due to the inefficiency of transparent action. This is a string of negligence in disclosing personal information in any social media application that one wants to join without thinking about the bad consequences that will befall in the future. Lack of knowledge in the use of social media has caused many criminal cases to become more prevalent nowadays. The solution that can be practiced in an organization is to implement a code of ethics in the work system to maintain the confidentiality of information and the harmony of the work environment of the organization and staff. While the solution for an individual is, have the value of trust in maintaining the confidentiality of personal information for personal and family safety. The efficiency of maintaining personal information based on ethical transparency and integrity can dispel the problem of misuse of technology that arises.

\section{References}

Barnes, C. J. (2006). Preparing preservice teachers to teach in a culturally responsive way. Negro educational review, 57.

Chen, G., Sharma, P. N., Edinger, S., Shapiro, D., \& Farh, J. (2011). Motivating and demotivating forces in teams: Cross-level influence of empowering leadership and relationship conflict. Journal of Applied Psychology, 96, 541-57. 
Culnan, M. J., McHugh, P. J., \& Zubillaga, J. I. (2010). How large US companies can use Twitter and other social media to gain business value. MIS Quarterly Executive, 9(4). https://aisnet.org/misqe/vol9/iss4/6.

Deiser, R., \& Newton, S. (2013). Six social-media skills every leader needs. McKinsey Quartly, 1,62-75.

Deluga, R. J. (1998). Leader-member exchange quality and effectiveness ratings: The role of subordinate-supervisor conscientiousness similarity. Group and Organization Management, 23(2),189-216.

Eddy, S. N., \& Greg J. S. (2012). Diversity Practices: Moderating effects of social values and age. Journal Business Ethics, 105, 41-52.

Goodyear, P., \& Ellis, R. (2008). University students' approaches to learning. Distance Education, 29(2), 141-52.

Gordon, P. T. (2014). Are you connected? Leadership in the era of social media. Development and Learning in Organizations: An International Journal, 28(6), 9-11.

Huang, X., Yun, J., Liu, J., \& Gong, Y. (2010). Does participative leadership enhance work performance by inducing empowerment or trust? The differential effects on managerial and non-managerial subordinates. Journal of Organizational Behavior, 31, 122-43.

Kaplan, A. M., \& Haenlein, M. (2010). Users of the world, unite! The challenges and opportunities of social media. Business Horizons, 53(1), 59-68.

Khalidah, K. A., Rohani, S., \& Mashitah, S. (2014). Ethical values and commitment towards achieving excellence: A study on public boarding school students in Malaysia. Pertanika Journal of Social Sciences \& Humanities, 22, 33-50.

Kirkman, B. L., \& Rosen, B. (1999). Beyond self-management: Antecedents and consequences of team empowerment. Academy of Management Journal, 42, 58-74.

Leanna, L., Tuvana, R., \& Chun, G. (2014). The interaction between learning styles, ethics education, and ethical climate. Journal of Management Development, 33(6), 580-593.

Lee, M., \& McLoughlin, C. (2010). Web 2.0 -based e-learning. Information Science Reference, 43.

Li, C. (2010). Open leadership: How social technology can transform the way you lead. John Wiley \& Sons.

Malaysian Institute of Integrity and National Integrity Plan. (2016). http://pmr.penerangan.gov.my/index.php/budaya/6633-budaya-etika-dan-integritimembentuk-budaya-kerja-cemerlang.html.

Mark, B. (2010). How social media can and should impact higher education. Distance learning/technology. http://www.wdhstore.com/hispanic/data/pdf/nov29howsocial.pdf.

Michael, P. L., \& Jacqueline, B. (2014). What does ethics have to do with leadership? Journal Business Ethics, 124, 225-242.

Moran, M., Seaman, J., \& Tinti, K. H. (2011). Teaching, learning, and sharing: How today's higher education faculty use social media. Pearson Learning Solutions \& Babson Survey Research Group. (Pearson Social Media Survey 2010).

http://www.slideshare.net/PearsonLearningSolutions/pearsonsocialmediasurvey2010.

Ramaiah, A. L. (1999). Kepimpinan Pendidikan: Cabaran masa kini (edisi baru). IBS Buku Sdn. Bhd.

Seibert, S. E., Sparrowe, R. T., \& Liden, R. C. (2003). A group exchange structure approach to leadership in groups. Sage Publications. 
Thomas, D., \& Seely-Brown, J. (2011). A new culture of learning. Charleston, SC, Createspace. http://sites.duke.edu/arthist110_001_f2011/files/2011/08/Thomas_Brown_A_New_C ulture_of_Learning.pdf.

Widodo, J. (2011). Leadership 2.0: Sebuah paradigma kepemimpinan actual. Forum Manajemen Prasetya Mulya, 25(1).

Yukl, G., \& Becker, W. (2006). Effective empowerment in organizations. Organization Management Journal, 3, 210-31. 